doi:10.18575/msrs.sm.e.15.02

UDC: $616.314-002-084-053.2$ COBISS.RS-ID 5325080

\title{
Assessment of Efficiency of the Preventive Programme on Caries Prevalence in Primary School Children
}

\begin{abstract}
Introduction: According to the World Health Organisation (WHO) reports, dental caries remains a major tooth disease affecting 60-90\% of children and practically $100 \%$ of adults and is one of the main reasons for premature loss of teeth.

Distribution of caries among school children in their final grades of primary school is highly pronounced and it requires a lot of financial resources for sanation which cannot be provided without reducing pathology and making serious changes in the organisation of preventive dental service.
\end{abstract}

Aim of the study: The aim of the study is to assess the efficiency of implemented preventive activities in lower grades of primary school on the prevalence of caries among children in their final grades.

Patients and Methods: The research was conducted longitudinally from September 2005 until March 2013. The research included 100 children of both sexes, 48 girls and 52 boys, who were chosen randomly from two primary schools in Banja Luka. The first school had a school dental clinic and the preventive programme with periodical systematic dental examinations was conducted. The second school didn't have a school dental clinic and the preventive programme was not conducted there; only systematic dental examinations at the same time when they were conducted in the first school. By conducting dental examination, the number of present permanent teeth, caries presence, existing fillings, and oral hygene status were recorded.

Results: Parameters of health status recorded in the total sample are alarming. The values of CIA index were 1.1 in children aged 6-7 years, 3.2 in children aged 8-9 years and 6.9 in children aged 13-14 years. The values of SIC index ranged from 2.9 in children aged 6-7 years, 4.9 in children aged 8-9 years to 10.7 in children aged 13-14 years.

Conclusion: Preventive activities implemented in lower grades of primary school, based on health education of children with demonstration on a model and without additional preventive interventions (fissure sealing, teeth brushing with higher-fluorideconcentration toothpastes), did not have impact on the prevalence of caries in final grades.

Keywords: caries, oral health, preventive programme

\section{Ranka Knežević ${ }^{1}$, Sanja Ilić ${ }^{1}$ Radmila Arbutina ${ }^{2}$}

${ }^{1}$ Public Health Institution Institute of Dentistry , Banja Luka, Republic of Srpska

${ }^{2}$ Faculty of Medicine University of Banja Luka, study programme dentistry, Republic of Srpska

\section{Contact address:}

Ranka Knežević

Lazarička 28,

7800 o Banjaluka, BiH

E-mail:

rankaknezevic25@gmail.com

Tel ( mob): +38765242444 


\section{Introduction}

Oral cavity is an important part of organism where significant physiological activities are taking place and through which an important communication with the outside environment is being accomplished. It is a very complex ecological structure with a persistence of over 700 types of microorganisms discovered so far and which have certain roles and their balance is necessary for normal homeostasis. The consequences of its disturbance are reflected on disorders of both local and general functions..$^{1-3}$ Teeth have multiple roles in the development and homeostasis of the whole orofacial system, but also in the functioning of the whole organism and not just the digestive system. ${ }^{4}$

Caries certainly remains the most significant tooth disease affecting, according to the WHO reports, 60-90\% of children and practically $100 \%$ of adults and it is one of the main reasons for premature tooth loss. ${ }^{5,6}$ According to Vojinovic et al., it is a destructive post-eruptive process on dental tissues of infectious origin which starts with the demineralisation of enamel and dentin by creating defects (cavities) through which infection continues to spread on the dental pulp. ${ }^{7}$

Distribution of teeth and gum diseases in final-gradesprimary-school-children in Banja Luka is very pronounced and it requires a lot of financial resources for sanation which cannot be provided without reducing pathology and making serious changes in the organisation of preventive dental protection.

Preventive programme which includes education on importance of oral health maintenance as well as demonstration of proper teeth brushing technique in lower primary school grades shows some short-term improvements, but it does not have a long-term motivational effects.

\section{Aim of the study}

The aims of the research were as follows:

- To assess the prevalence of caries in school children aged 13-14 years in Banja Luka.

- To assess the effects of preventive programme implemented in lower grades of primary school (aged 6-9 years) on caries prevalence in children in their final grades (aged 13-14 years).

- To assess the effects of the monitored preventive programme in lower grades of primary school on the degree of teeth sanation in final grades (aged 13-14 years).

\section{Patients and Methods}

The research was conducted longitudinally from September 2005 until March 2013. The research included 100 children of both sexes, 48 girls and 52 boys, who were chosen randomly from two primary schools in Banja Luka.
Primary school "Ivo Andric"” was chosen as an experimental school while Primary school "Đura Jakšić" was chosen as a control school.

The children in both schools were examined:

- at the beginning of the first grade of the school year 2005/2006 (aged 6-7 years),

- in the fourth grade of the school year 2008/2009 (aged 8-9 years),

- in the eighth grade of the 2012/2013 school year (aged 13-14 years).

The experimental group comprised of 50 pupils of "Ivo Andrić" Primary School, 26 girls and 24 boys, who underwent the preventive programme during the period from September 2005 to April 2008. The programme was based on health education and local fluorid application with practical demonstration on education model.

Preventive activities were conducted twice a month and included the following:

1. Promotion of health in the form of lectures on oral hygiene and the importance of mouth and teeth health maintenance.

2. Dental plaque identification with tablets

3. Teeth brushing with mild concentration fluoride solution (Fluorogal mite $\AA$ solution, 2000 ppm,) with practical demonstration of proper technique for brushing teeth by using educational model

4. Systematic examinations in 2005, 2008 and 2013.

5. Provided dental health protection in dental clinic within school.

The control group comprised 50 pupils of " Đura Jakšić" Primary School, 22 female and 28 male pupils, who were not constantly provided with preventive services.

This group of children underwent only systematic examinations in 2005, 2008 and 2013.

Primary School "Đura Jakšić" did not have dental clinic within the school and these children received dental services in dental clinics within other primary schools.

Dental examination in each analysed year was performed by the same team of dentists, based on the WHO criteria (WHO, Oral health Surveys-methods, 4th edition, Geneva,1997). ${ }^{8}$ Examination was carried out under artificial light using a dental probe and a mirror. Only permanent teeth were examined.

The presence of white stains and enamel and dentin defect based on visual picture or probe stucking were marked as 
caries. The existing fillings, extracted (missing) teeth and oral hygiene status were also registered.

The obtained results were presented in the form of epidemiological indices:

- The DMFT index, defined by Klein and Palmer, is the most widely accepted index in epidemiologic surveys of caries and it represents the sum of decayed, missing and filled permanent teeth. ${ }^{5}$

- CIT (Caries Index of Teeth) represents the percentage of decayed teeth in relation to all examined permanent teeth. ${ }^{5}$

- CIP (Caries Index of Persons) represents the percentage of persons in population with at least one decayed permanent tooth. With a decrease in caries prevalence, the changed variation of CIP index becomes increasingly important indicator of dental health status and it shows the percentage of persons with all healthy teeth, internationally defined by the term "caries free". ${ }^{5}$

- CIA (Caries Index Average) represents the average number of decayed permanent teeth per person and it is the most common way of showing caries prevalence. ${ }^{5}$

- SIC (Significant Caries Index) is calculated by taking the examined population in percentages according to the DMFT value. The one third of the population with the highest DMFT index is selected and the CIA for this group is calculated separately. ${ }^{5}$

- OHI (Oral Hygiene Index) is used for the assessment of oral hygiene. The area of tooth surface covered with soft plaque is checked by periodontal probe and the average index is calculated when the values obtained are added together after which the sum is divided by the number of the teeth examined. ${ }^{9}$

The data collected were statistically analysed in $I B M$ SPSS Statistics software. Methods used in statistical data analysis are from the domain of descriptive statistics and statistical conclusion. Following descriptive measures were used: arithmetic mean, standard deviation, coefficient of variation, median and proportion. In order to register the presence of statistically significant difference the t-test, Ztest, method chi- square test were used.

The essence of statistical data analysis is reflected in an analysis of difference between the above-mentioned schools in three different periods (2005, 2008 and 2013) on the basis of various parameters which were observed.

\section{Results}

The data for the year 2005 (Table 1.) indicate that there were no significant differences between experimental and control schools. Extremely high values of epidemiological indices monitoring in experimental school CIA (caries index average) $=1.15$, CIT (caries index of teeth) $=11.4 \%$, $\mathrm{SIC}=2.9$ and in control school with CIA (caries index average) $=1.24, \mathrm{CIT}=11.8 \%$, SIC $=3$ suggest extremely high starting point of pathology related to the permanent teeth. This analysis, conducted for the first time for the area of the Republic of Srpska, also showed the SIC index which was 2.9 in the experimental school and 3.0 in the control school. The percentage of children without caries was $50 \%$ in experimental and $54 \%$ in control school.

Table 1. Results of systematic examination in 2005 (age 6-7 years)

\begin{tabular}{|c|c|c|c|c|c|c|c|c|c|c|c|}
\hline & $\begin{array}{c}\text { Teeth } \\
\text { present }\end{array}$ & $\begin{array}{c}\text { Percentage } \\
\text { of caries free } \\
\text { children }\end{array}$ & $\begin{array}{l}\text { Decayed } \\
\text { teeth } \\
\text {-caries (D) }\end{array}$ & $\begin{array}{l}\text { Missing teeth- } \\
\text { extractions (M) }\end{array}$ & $\begin{array}{l}\text { Filling } \\
(F)\end{array}$ & $\begin{array}{l}\text { Degree of } \\
\text { sanation } \\
\text { F/DMFT }\end{array}$ & $\mathrm{CIA}$ & CIT & $\mathrm{SIC}$ & DMFT & $\mathrm{OHI}$ \\
\hline $\begin{array}{l}\text { Experimental } \\
\text { school }\end{array}$ & 497 & $50 \%$ & 47 & 0 & 10 & $18 \%$ & 1.15 & $11.4 \%$ & 2.9 & 57 & 1.15 \\
\hline Control school & 497 & $54 \%$ & 47 & 5 & 7 & $12 \%$ & 1.24 & $11.8 \%$ & 3.0 & 59 & 1.15 \\
\hline $\begin{array}{l}\text { Statistical } \\
\text { significance }\end{array}$ & 1.00 & 0.689 & 1.00 & 0.022 & 0.622 & 0.395 & 0.384 & 0.873 & 0.201 & 0.893 & 0.011 \\
\hline
\end{tabular}

Table 2. Results of systematic examination in 2008 (age 8-9 years)

\begin{tabular}{lcccccccccccccccccc}
\hline & $\begin{array}{c}\text { Teeth } \\
\text { present }\end{array}$ & $\begin{array}{c}\text { Percentage } \\
\text { of caries free } \\
\text { children }\end{array}$ & $\begin{array}{c}\text { Decayed } \\
\text { teeth } \\
\text {-caries (D) }\end{array}$ & $\begin{array}{c}\text { Missing teeth- } \\
\text { extractions (M) }\end{array}$ & $\begin{array}{c}\text { Filling } \\
(\mathrm{F})\end{array}$ & $\begin{array}{c}\text { Degree of } \\
\text { sanation } \\
\text { F/DMFT }\end{array}$ & CIA & CIT & SIC DMFT & OHI \\
\hline $\begin{array}{l}\text { Experimental } \\
\text { school }\end{array}$ & 843 & $16 \%$ & 101 & 5 & 44 & $29 \%$ & 3.0 & $17.7 \%$ & 4.8 & 150 & 0.9 \\
\hline Control school & 856 & $2 \%$ & 146 & 15 & 16 & $9 \%$ & 3.54 & $20.6 \%$ & 5.1 & 177 & 1.82 \\
\hline $\begin{array}{l}\text { Statistical } \\
\text { significance }\end{array}$ & 0.693 & 0.019 & 0.003 & 0.033 & 0.009 & 0.010 & 0.131 & 0.704 & 0.2 & 0.131 & 0.03 \\
\hline
\end{tabular}


The results of dental examinations in 2008 (Table 2.) suggest that the percentage of children without caries ranged from $16 \%$ of children in experimental to $2 \%$ of children in control school.

Statistically significant difference between the schools exists in the percentage of persons without caries as well as in the oral hygiene index. The structure of DMFT shows statistically significant differences in parameters D (decayed teeth), M (missing/extracted teeth), F (filled teeth) and higher sanation degree of the experimental in comparison with the control school. The values of epidemiological indices in the experimental school were: $\mathrm{CIA}=3.0, \mathrm{CIT}=17.7 \%, \mathrm{SIC}=4.8$ and in the control school: $\mathrm{CIA}=3.54, \mathrm{CIT}=20.6 \%, \mathrm{SIC}=5.1$.

The final results, registered in 2013, suggest that previously noticed statistically significant differences were not registered when it came to the percentage of persons without caries, marked in 2008. (Table 3.).

Table 3. Results of systematic examination in 2013 (age 13-14 years)

\begin{tabular}{lcccccccccccc}
\hline & $\begin{array}{c}\text { Teeth } \\
\text { present }\end{array}$ & $\begin{array}{c}\text { Percentage } \\
\text { of caries free } \\
\text { children }\end{array}$ & $\begin{array}{c}\text { Decayed } \\
\text { teeth } \\
\text {-caries (D) }\end{array}$ & $\begin{array}{c}\text { Missing } \\
\text { teeth- } \\
\text { extractions } \\
(M)\end{array}$ & $\begin{array}{c}\text { Filling } \\
(\mathrm{F})\end{array}$ & $\begin{array}{c}\text { Degree of } \\
\text { sanation } \\
\text { F/DMFT }\end{array}$ & CIA & CIT & SIC & DMFT & OHI \\
\hline Experimental school & 1.402 & $2 \%$ & 144 & 10 & 182 & $54 \%$ & 6.7 & $23.0 \%$ & 9.52 & 336 & 1.54 \\
\hline Control school & 1.398 & $1 \%$ & 219 & 65 & 67 & $19 \%$ & 7.0 & $24.9 \%$ & 11.9 & 351 & 1.71 \\
\hline $\begin{array}{l}\text { Statistical } \\
\text { significance }\end{array}$ & 0.851 & 0.719 & 0.002 & 0.10 & 0.00 & 0.00 & 0.677 & 0.904 & 0.220 & 0.676 & 0.432 \\
\hline
\end{tabular}

There was a statistically significant difference in the number of decayed and filled teeth, and in the degree of sanation. The values of epidemiological indices for the experimental school were: $\mathrm{CIA}=6.7, \mathrm{CIT}=23 \%$, SIC $=9.52$ and for the control school: $\mathrm{CIA}=7.0$. $\mathrm{CIT}=24.9 \%, \mathrm{SIC}=11.9$.

\section{Discussion}

Increase of dental pathology in school children requires a review of the doctrine which proposes a systematic school dental care. ${ }^{9-15}$ In support of this view are also majority of studies coming from the countries with significant decrease of caries prevalence, indicating much smaller importance of the effect of health and education in schools in relation to the application of fluoride..$^{16}$ It can also be noted that there is a significant effect of caries in deciduous dentition on teeth disease in permanent dentition. ${ }^{9-15}$ Initial health status registered in both groups found no significant differences when it came to the existing pathology. A significant difference was only registered in the number of extracted teeth and the value of OHI. Situation was worse in the control school which was in the suburban area and without dental clinic within the school.

Registered parameters of health status in total sample showed alarming values since the percentage of 13-year-old children without caries amounted to $1-2 \%$. The number of 12-year-old children without caries in developed European countries ranges from $25-60 \%$ while that percentage is much lower in the former socialist (Eastern European) countries, but still above $10 \% .{ }^{13,16}$ When it comes to the neighboring countries, 12-year-old children without caries in Serbia make up 20\%, in Croatia about 10\% and negligible
$1 \%$ in Foča ${ }^{11,17}$ According to the WHO global goals, it is recommended that by the year 2010 CIA in 12-yearold children gets under 1 on a national level and for the year 2020 it is recommended to increase a proportion of children without caries as well as to reduce risk groups. ${ }^{18,19}$

Recent epidemiological studies in the world in the era of caries prevalence reduction indicated certain limitations in the appliance of CIA index. There is a division in population between the group with high and very high CIA index and a number of persons without caries which can lead to the false conclusion if the findings are interpreted and analysed only based on the CIA index. For that reason, at the beginning of the year 2000, a new Caries Significant Index (SIC index) was introduced and it marks the presence of caries in one third of those with the highest score. ${ }^{18}$ Simultaneous analysis of the CIA and SIC indices provides better interpretation of the presence of pathology and possible treatment, especially in conditions limited by the financial and/or staff possibilities, which is our case. There have been various suggestions and some of them proposed having the SIC below 3 for the age of 12 set along with the CIA below 1 as a global goal. ${ }^{18}$ Other proposals give greater importance, from the point of planning, to the observation of 15-year-olds instead of 12-year-olds with the goal of SIC being less than $5 .{ }^{20}$

If we observe control and experimental group together, the results of research show high values of both CIA and SIC. (Tables 1, 2 and 3). If we include a small percentage of children without caries in all examined periods, we get relatively homogeneous high caries presence. No significant differences in the SIC between the schools showed the lack 
of any significant changes in risk population, regardless of the preventive activities and the existence of dental clinic in one of the schools.

If we compare the SIC results with the findings in other countries (Table 4.) which are shown for the age of 12 , the values of 11.9 at the age of 13 for our area show, by far, unsatisfactory condition in relation to the majority presented, especially European countries. The values of SIC shown and presented in this study are among the first that have been published for the region of Banja Luka and the Republic of Srpska.

Table 4. CIA and SIC in different countries according to the size of the CIA

\begin{tabular}{lllll}
\hline Country & $\begin{array}{l}\text { KIP in } \\
12-y e a r- \\
\text { olds }\end{array}$ & SIC & $\begin{array}{l}\text { Examination } \\
\text { year }\end{array}$ & $\begin{array}{l}\text { Sample } \\
\text { size }\end{array}$ \\
\hline Australia & 0.8 & 2.4 & 1999 & 2913 \\
\hline Sweden & 0.9 & 2.6 & 2001 & 71.896 \\
\hline China & 1.0 & 3 & 1996 & 23.452 \\
\hline England (UK) & 1.4 & 3.2 & $2000-2001$ & 12.029 \\
\hline SAD & 1.4 & 3.6 & $1988-1991$ & 176 \\
\hline Germany & 1.7 & 4.1 & 1997 & 1.043 \\
\hline Israel & 1.7 & 4.1 & 2002 & 1.327 \\
\hline Greece (Northern- & 1.8 & 4.2 & 2001 & 2.217 \\
\hline Eastern) & 1.8 & 4.3 & $1996-1997$ & 6.165 \\
\hline Scotland & 2.0 & 4.7 & 1998 & 6.000 \\
\hline France & 2.5 & 5.0 & 1997 & 1.138 \\
\hline Mexico & 2.7 & 5.4 & 1999 & 2.537 \\
\hline Belarus & 2.7 & 5.8 & 2001 & 785 \\
\hline Romania & 3.8 & 7.1 & 1998 & 416 \\
\hline Latvia & 3.9 & 7.2 & 1997 & 1.732 \\
\hline Poland & 5.9 & 14.3 & 1998 & 1.589 \\
\hline Slovakia & & &
\end{tabular}

Statistically significant difference in the year 2008 is present in a percentage of persons without caries, number of extracted, decayed and filled teeth, oral hygiene index, and the degree of teeth sanation (Table 2). This can be considered as a result of implemented preventive activities. The results in the year 2003 (Table 3) indicated that the difference in the number of decayed and filled teeth as well as the degree of sanation still remained.

When it comes to the key indicators of health such as the CIA and SIC indices that difference neither existed when the implementation started nor after the implementation of the programme. (Table 1, 2 and 3). There also wasn't a statistically significant difference in the total presence of decayed teeth (CIT). Their number in the experimental school increased from $11.4 \%$ to $17.7 \%$, and from $11.8 \%$ to
20.6\% in the control school (Tables 1 and 2). Motivation that children received during the programme in the experimental school had an influence on keeping the advantage regarding the absence of caries and on a large number of filled teeth. However, 50\% of children without caries at the age of eight, when on the average nine teeth were present per child, indicates very poor condition (Table 1.). The situation was even worse in 2008 upon the end of the programme when the children had on the average 17 newlyerupted teeth, out of which 3.5 in the control and 3 in the experimental school were already affected by the disease. (Table 2.).

Although our study did not registered the health status of deciduous teeth, the research from the similar period conducted by Dolic ${ }^{12}$ and Obradovic ${ }^{21}$ in Banja Luka showed high caries prevalence in deciduous teeth in the 6-yearolds $(\mathrm{CIA}=6$, without caries $=5 \%$ ). The first permanent molars erupted in such infected area and since there wasn't a programme of systematic fissure sealing during school enrollment and during the first grade, the majority of the first permanent molars in children in both schools at the beginning of the programme (the year 2005) was already carious. Large number of children without caries in the experimental group upon the completion of the programme in 2008 (Table 2.) was probably due to the sealed first permanent molars which were not affected by caries and it is also the result of preventive activities for which we assume had an impact on oral hygiene maintenance.

Significant difference in the number of D (decayed) component in the structure of DMFT is logical consequence of the presence of school dental clinic, so the children had better possibility and were also directly sent for sanation (Table 3.). As for the M (missing) component, there was an increase in both groups, but the experimental group did not have extracted/missing teeth from the starting point while their number reached five in the year 2008. The control group already started with five extracted/missing teeth which increased for ten. The existence of dental clinic and direct sending of the children also helped in timely detection and sanation of caries as well as in prevention of more extracted teeth (Table 3.).

By observing the $\mathrm{OH}$ index it can be noticed that at the beginning (the year 2005) there was no difference between the experimental and the control group (1.14 to 1.15) (Table 1.). However, in 2008 this index was about $50 \%$ better in the experimental group (o.9 to 1.82) (Table 2.) which can be interpreted as a result of health education measures.

Historically observed, health education was mainly an integral part of school dental care and its efficiency was assumed. Its goal was to motivate the target groups to maintain their oral hygiene regularly and to change their eating habits, especially when it came to sugar use. It was an integral part of school curricula in many schools 
in the world because it was believed that dental diseases were the consequence of bad habits and that educational environment in school should be a logical place where one can learn about healthy behaviour that would later in life result in the improvement of health. ${ }^{7,22-26}$ However, before local fluorid application there were no health improvements and the effects were primarily in the degree of sanation of the growing pathology. Research from that period showed a lot of contradictions with some suggesting the improvement of health indicators while others were denying them..$^{22,23}$ One detailed study conducted by the WHO and one research in Denmark have indicated that gingival health tended to be better among children in countries with longstanding school dental care programmes. ${ }^{22,27}$ With that in mind, the campaign which included opening of school dental clinics was initiated in the area of the former SFRY (The Socialist Federal Republic of Yugoslavia) during the 1970 s and 1980s, but the results of health improvement were obviously not the same as in some other developed countries. ${ }^{10}$ The research confirms these statements. For this reason, in 1978 Roder et al. ${ }^{23}$ suggested monitoring of health education effects in real programmes, in conditions set up in non-experimental manner through longitudinal monitoring of large groups of children instead of crosssectional study of different groups and ages. In our research we used the same approach, monitoring of children within regular activities of a dental team. Interpretation of importance of health education within school dental care is getting even more complicated with obvious results of a decrease in caries prevalence in developed countries during the 1980 s $^{28}$, whereas in underdeveloped countries the existence of organised school dental care did not influence the level of caries descreased. ${ }^{8,29}$ The greatest influence is given to the fluoride toothpastes which have been overtaking the majority of market in all developed countries since the end of the 1970s by conducting extensive campaigns and the increase of its use directly coincides with the decrease of caries. $7,8,30,3^{1}$ This initiated a new school programme efficiency testing since they were taking significant resources in some countries. The change of epidemiologic picture is also based on the polarisation of persons with or with minimum of caries on one side and high-risk individuals with large number of lesions on another one. During the 1980 s it was already clearly noted already that about $20 \%$ of high-risk individuals in population take over $70 \%$ of all carious lesions. ${ }^{5,30,32}$ This leads to the conclusion that classic preventive measures for the whole population no longer have economic justification.

\section{Conclusion}

Final results registered in 2013,which in the 13-year-old children are in average seven decayed teeth per person, indicate the presence of extremely high caries prevalence.

Preventive activities conducted in the lower primary school grades which were based on independent health and education, without additional preventive interventions (fissure sealing, teeth brushing with high-fluoride toothpastes), did not have influence on caries prevalence in final grades.

The preventive programme and school dental clinic provide better degree of teeth sanation in the schools where such exist and are implemented. However, the degree of sanation, which was $54 \%$ in the final grades, is extremely low to meet the standards of a well-organised dental service.

The results obtained indicate that an organised prevention should begin before the school age since otherwise it would be too late to slow down the growing pathology.

There have been suggestions about new approaches according to which preventive activities should be applied much earlier i.e. already in pregnancy in mothers and in early childhood in order to reduce caries in deciduous teeth, which would result in health improvement of permanent teeth.

\section{References}

1. Ślebioda Z, Szponar E, Kowalska A.Defensins and their role in the maintenance of the oral cavity homeostasis - a literature review. CentrEurJ Immunol 2013; 38 (1): 111-117.

2. Simón-Soro A, Tomás I, Cabrera-Rubio R, et al. Microbial geography of the oral cavity. J Dent Res. 2013 Jul;92(7):616-21. http:// dx.doi.org/10.1177/0022034513488119 PMid:23674263

3. King A.Oral Health - More Than Just Cavities. A Report by Ontario's Chief Medical OfficerofHealth.April2012; Available from: http://www.health.gov.on.ca/en/common/ministry/publications/reports/oralhealth/oralhealth.pdf

4. Elena K. Oralna fiziologija.Beograd: Zavod za udžbenike Beograd; 2009.

5. Vojinović J. Organizovana prevencija u stomatologiji,Banja Luka: Medicinski fakultet u Banjoj Luci; 2012.

6. Petersen PE. Sociobehavioural risk factors in dental caries - international perspectives Community Dent Oral Epidemiol 2005; 33: 274-9. http://dx.doi.org/10.1111/j.1600-0528.2005.00235.x PMid:16008634

7. Vojinović J, Tatić E, Anđelić P, Pintarić J. Preventivni program u stomatologiji. Beograd: Naučna knjiga Beograd; 1990.

8. Oral health Surveys-methods.Geneva 4th edition; WHO,1997.

9. Zelić, O: Osnovi kliničke parodontologije, Beograd: Stomatološki fakultet Beograd; 2002.

10. Marhaler T.Changes in Dental Caries 1953-2003. Caries Res. 2004;38:173-181.

11. Alm A et al.Caries in adolescence-influence from early childhood. Community Dent Oral Epidemiol. 2012; 40(2):125-33. http:// dx.doi.org/10.1111/j.1600-0528.2011.00647.x PMid:22022978

12. Vrbič V.Oral health in Yugoslavia. WHO, Eur/YUG/ORH, Geneva: 1991. PMid:2049926

13. JurićH, KlarićT, Žagar M, Buković D JR, Janković B, Špalj S. Incidence of caries in children of rural ana subrural areas in Croa- 
tia.Coll Antropol. 2008;32:131-6. PMid:18494198

14. Dolic O, Vojinović J, Đukanović D,Čupić S, Sukara S, Obradović $\mathrm{M}$, et al. Caries prevalence in primary and permanente dentition in rural and urban children in Municipality of Banja Luka BiH. HDMBSC. 2010; 9(1):41-47.

15. Ivanović M, Carević M, Marković D, Vulićević Z, Stevanović R, Petrović V et al. Protocols in dentistry. Belgrade: School of Dentistry; 2009.

16. Rogers JG. Evidence-based oral health promotion resources. Prevention and Population Health Branch, Govermant of Victoria, department of Health, Melbourne: 2011.

17. Heidi wiki. Dental and oral diseases. Availableat:https://webgate.ec.europa.eu/sanacio/heidi/index.php/Heidi/Major_and_ chronic-diseases/Dental_and_oral_diseases\#cite_ref-7on 03/05/2012

18. Davidović B, Ivanović M, Janković S. Dental Health Estimation for Children Age Twelve and Fifteen.Serbian Dental J. 2012;59(1):35-43. http://dx.doi.org/10.2298/SGS1201035D

19. Bratthall D. Introducing the Significant Caries Index together with a proposal for a new global oral health goal for 12-yearolds. Int Dent J. 2000;50:378-84. http://dx.doi.org/10.1111/ j.1875-595X.200o.tboo572.x PMid:11197197

20. Hobdell $\mathrm{M}$ et al. Global goals for oral health XX International Dental Journal. 2003; 53: 285-288. http://dx.doi.org/10.1111/ j.1875-595X.2003.tboo761.x PMid:14560802

21. Marthaler T, Menghini G, Steiner M. Use of the Significant Caries Index in quantifying the changes in caries in Switzerland from 1964 to 2000. Community Dent Oral Epidemiol. 2005; 33:159166.http://dx.doi.org/10.1111/j.1600-0528.2005.00196.x PMid:15853838

22. Obradović M. Oralno zdravlje djece uzrasta do 6 godina u predškolskim ustanovama grada Banjaluka - magistarska teza. Medicinski fakultet Banja Luka; 2010.
23. Roder DM, Burt BA. Evaluation of dental health education in a school dental care program. Journal of Public Health Dentistry, 1978; 38:44-57. http://dx.doi.org/10.1111/j.1752-7325.1978. tbo3715.x

24. Rayner, Jeannette F, Cohen Lois K.School dental health education. p. 275-307. (In Richards,N. D, Cohen Lois K. et al. Social sciences and dentistry: a critical bibliography. The Hague, 1971

25. Effectiveness of oral health promotion Health promotion.NHS Health Development agency,Summary bulletin 7:1997.

26. Applewhite H. Dental health education in the schools. Am. J. Pub. Health, 1970; 60:1835-8. http://dx.doi.org/10.2105/ AJPH.60.9.1385

27. Cohen LoisK,Lncye H. A position on school dental health education. J. Sch. Health. 1970; 40:361-5. http://dx.doi. org/10.1111/j.1746-1561.1970.tbo5624.x

28. Holst, Dorthe. Prevalence of gingivitis among children with and without school dental service. Scand. J. Dent. Res.1976; 84:1507. http://dx.doi.org/10.1111/j.160o-0722.1976.tboo473.x

29. Campus $\mathrm{G}$ et al, Changing trend of caries from 1989 to 2004 among 12-year old Sardinian children, BMC Public Health. 2007; 7:28. http://dx.doi.org/10.1186/1471-2458-7-28 PMid:17331258 PMCid:PMC1832181

30. Marthaler TM, O'Mullane DM, Vrbic V. The prevalence of dental caries in Europe1990-1995.Caries Res. 1996; 30:237-255. http:// dx.doi.org/10.1159/000262332 PMid:8773416

31. Burt BA. Concepts of risk in dental public health. Community Dent Oral Epidemiol. 2005; 33:240-247 http://dx.doi. org/10.1111/j.1600-0528.2005.00231.x PMid:16008630

32. Beltran-Aguilar ED et al. Centers for Disease Control and Prevention (CDC). Surveillance for dental caries, dental sea lants, tooth retention, edentulism, and enamel fluorosis - United States, 1988-1994 and 1999-2002.MMWR Surveill Summ 2005; 54:143. PMid:16121123

\section{Utvrđivanje efikasnosti preventivnog programa na prevalencu karijesa kod djece u osnovnoj školi}

\section{SAŽETAK}

Uvod: Prema izvještajima Svjetske zdravstvene organizacije (SZO), karijes zuba (caries dentes) je još uvijek najznačajnije oboljenje zuba, od koga boluje 60-90\% djece i praktično 100\% odraslih osoba i jedan je od glavnih razloga preranog gubitka zuba. Rasprostranjenost karijesa kod djece u završnim razredima osnovne škole je veoma izražena i zahtijeva velika finansijska sredstva za sanaciju, što se ne može obezbijediti bez smanjenja patologije i ozbiljnih promjena u organizaciji preventivne stomatološke službe.

Cilj rada: Utvrditi efikasnost sprovođenih preventivnih aktivnosti u nižim razredima osnovne škole na prevalencu karijesa kod djece u završnim razredima.

Ispitanici i metode: Istraživanje je sprovedeno longitudinalno u periodu od septembra 2005. godine do marta 2013. godine. U istraživanju je učestvovalo 100 djece, oba pola, izabranih metodom slučajnog izbora iz dvije osnovne škole u Banjoj Luci. U jednoj školi je postojala stomatološka ambulanta i sprovođen je preventivni program uz periodične stomatološke sistematske 
preglede. Druga škola nije posjedovala ambulantu, u njoj nije sprovođen preventivni program, već su samo vršeni stomatološki sistematski pregledi kada i u prvoj školi. Stomatološkim pregledom se registrovao broj prisutnih stalnih zuba, prisutnost karijesa, postojeći ispuni, te stanje oralne higijene.

Rezultati: Zabilježeni parametri zdravstvenog stanja kod kompletnog uzorka pokazuju zabrinjavajuće vrijednosti. Vrijednosti KIP-a su 1,1 u uzrastu 6-7 godina, te 3,2 u uzrastu 8-9 godina i 6,9 u uzrastu 13-14 godina. Vrijednosti SIC-a su se kretale od 2,9 u uzrastu 6-7 godina, preko 4,9 u uzrastu 8-9 godina do 10,7 u uzrastu 13-14 godina.

Zaključak: Preventivne aktivnosti koje su sprovođene u nižim razredima osnovne škole, a koje su bile bazirane na zdravstvenovaspitnom radu sa djecom uz demonstraciju na modelu, bez dodatnih preventivnih intervencija (zalivanje fisura, četkanje zuba pastama sa većom koncentracijom fluora), nisu imale uticaj na prevalencu karijesa u završnim razredima.

Ključne riječi: karijes, oralno zdravlje, preventivni program 